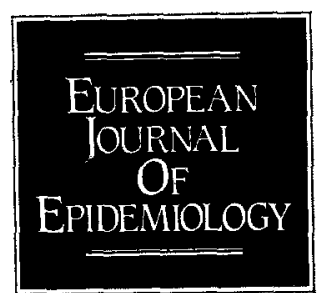

\title{
EPIDEMIOLOGICAL EVIDENCE THAT HTLV-III IS THE AIDS AGENT
}

\author{
J.J. GOEDERT * '. R.C. GALLO ** \\ * Environmental Epidemiology Branch, National Cancer Institute, Landow Building, \\ Bethesda, Maryland 20205, USA. \\ $\therefore *$ Laboratory of Tumor Cell Biology, National Cancer Institute, Building 37, Bethesda, \\ Maryland 20205, USA.
}

Key words: Retrovirus infections - Immunologic deficiency syndromes Homosexuality - Hemophilia.

Human T-lymphotropic virus type III (HTLV-III) is a recently discovered retrovirus with tropism and cytotoxicity for the OKT4+ lymphocytes that are depleted in the acquired immune deficiency syndrome (AIDS). In addition to the frequent detection of HTLV-III in patients with AIDS and related syndromes, seroepidemiological studies have shown that HTLV-III can be transmitted by sexual contact and blood transfusion in a manner identical to the putative AIDS agent. Analyses of stored sera have revealed that HTLV-III antibodies appeared in high-risk groups some two years before the disease outbreak, which corresponds to the apparent incubation period in patients with transfusion-associated AIDS. The risk of developing AIDS is clearly associated with HTLV-III seropositivity and may be as high as $20 \%$ within three years. Strong evidence that HTLV-III is the AIDS agent mandates aggressive efforts to minimize further sexual, maternal-fetal, and blood-borne transmission of this virus while pursuing vaccine development and antiretroviral therapies.

The acquired immune deficiency syndrome (AIDS) is an epidemic of highly lethal opportunistic infections and malignancies that was first reported in the United States and Europe during 1981 (1). In retrospect, cases of AIDS had first appeared in these areas during the late 1970s. By the end of 1982, two facts about AIDS were apparent. First, a full scale epidemic was in progress among homosexual men and parenteral drug users in the United States (Figure 1). Second, AIDS had been diagnosed in hemophiliacs, in transfusion recipients, and in the heterosexual partners of parenteral drug users, strongly suggesting that a blood-borne and sexually transmissible agent was responsible for AIDS (Figure 1). The vehicle for infecting hemophiliacs, clotting factors concentrate, is filtered to remove bacterial or fungal contamination; therefore, the AIDS agent had to be a virus or smaller particle. It was also clear that the immune deficiency of AIDS was caused by a selective depletion of helper-inducer (OKT4+) lymphocytes (2). In this setting, the search began for a virus with tropism and cytotoxicity for the OKT4 + lymphocyte population.

Various strains of a new human retrovirus variously termed human T-lymphotropic virus type III (HTLV-III) or lymphadenopaty-associated virus (LAV), have now been isolated by several independent laboratories, generally from lymphocytes, from the peripheral blood, bone marrow, lymph nodes, saliva, and semen of AIDS patients and persons at high of AIDS (3-10). As with the prototype human retroviruses HTLV-I and HTLV-II, HTLV-III has the three principal genes for viral replication: gag, which encodes viral core proteins; pol, wich encodes the enzyme

${ }^{1}$ Corresponding author. 


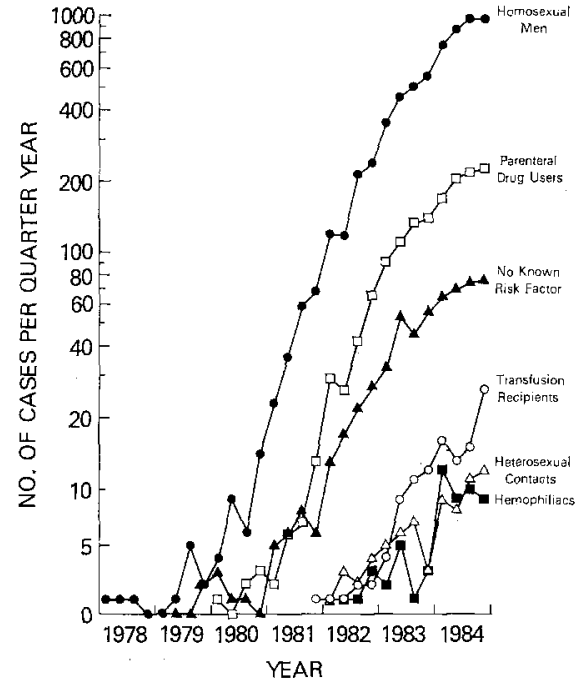

Figure 1. - Number of cases of AIDS per quarter year in the United States reported to the Centers for Disease Control by risk groups.

reverse transcriptase enabling the viral RNA genome to be transcribed into the DNA provirus copy that can be integrated into the host genome; env, which encodes viral envelope proteins; and an extra gene known as tat III, which encodes a protein that can transactivate other (viral and possibly cellular) genes. In addition, HTLV-III has at least 2 other genes whose functions are unclear. These viruses, while they can infect some other cells, have a strong tropism for the OKT4+ epitope. In vitro, HTLV-III is highly cytopathic for OKT4 + lymphocytes, usually with complete loss of this cell population within 2-3 weeks. Thus, the biologic properties of HTLV-III in cell culture are similar to the pathologic picture of AIDS in vivo. Reviews of the molecular biology of HTLV-III have been presented elsewhere (11-13). In addition to isolating the virus more than 100 times from the various clinical and demographic types of AIDS patients and persons at high risk of AIDS (10), a key step for epidemiological studies in demonstrating that HTLV-III is the primary etiological agent of AIDS was the establishment of HTLV-III in a permanently producing cell line and the development of antibody assays which have subsequently been applied to epidemiological studies (14).

\section{HTLV-III and AIDS in Homosexual Men}

Two cohort studies of homosexual men have provided strong evidence for the sexual transmission of HTLV-III and the subsequent development of AIDS and related conditions $(15,16)$. In a high risk cohort, in central New York City, the risk of HTLV-III seropositivity was closely asso- ciated with the number of homosexual partners and with the frequency of receptive anal intercourse (15). Other sexual pratices did not appear to increase the risk of HTLV.III seropositivity. Among the homosexual men in a relatively low risk cohort in Denmark, visiting the United States during the previous 2 years (1980-'81) was associated with an increased risk of having HTLV-III antibodies (16). In addition, among Danish homosexual men who did not visit the United States, sexual contact with Americans in Europe or sexual contact with AIDS patients also appeared to increase the risk of seropositivity. As was true in the New York cohort, the frequency of receptive intercourse, but not other sexual practices, was related to seropositivity in the Danish cohort (16).

Among the 66 homosexual men in New York City, HTLV-III seropositivity was very closely related to the fundamental immunologic abnormality of AIDS, decreasing helper T-cell counts $(r=-0.53, p=0.0001)$. This appeared to be true even among the 26 New York homosexual men who remained free of AIDS and related conditions $(\mathrm{r}=-0.37, \mathrm{p}=0.07)$. In contrast, HTLV-III seropotivity was not related to suppressor T-cell counts $(\mathrm{N}=66, \mathrm{r}=+0.17, \mathrm{p}=0.2)$. During the two years of follow-up, AIDS developed in 6 of the homosexual men in New York City, for a 2-year attack rate among seropositives of $14 \%$, and in 2 of the homosexual men in Denmark, for a 2-year attack rate of $9 \%$. An additional $2(9 \%)$ of the seropositive Danish homosexual men developed AIDSrelated complex, and $10(26 \%)$ of the New York homosexual men developed oral candidiasis, herpes zoster, or idiopathic thrombocytopenia, a complex termed « lesser AIDS ».

\section{HTLV-III and AIDS in Hemophiliacs}

AIDS among hemophiliacs has not been limited to any one geographic area of the United States, and hemophilia actually accounts for a higher proportion $(3.4 \%)$ of the Europeans with AIDS than the Americans with AIDS (1\%) (1). In the United States, the risk of AIDS among hemophiliacs is much higher with severe hemophilia A than with hemophilia B or milder forms of hemophilia A (17). Likewise, the prevalence of HTLVIII antibodies among hemophiliacs during 1982 was as high as $90 \%$ among hemophilia $A$ patients who received factor VIII concentrate at least twice a month compared to a very low rate of seropositivity among hemophilia $\mathrm{B}$ patients receiving factor IX concentrate or patients with mild hemophilia receiving cryoprecipitate or fresh frozen plasma (18). Among European hemophiliacs, the source of plasma that is made into factor VIII concentrate is closely related to the risk of HTLV-III seropositivity (19). In Scotland, where 
AIDS is rare and where clotting factor concentrates are locally prepared, hemophiliacs had an HTLV-III seroprevalence rate of $15.6 \%$ compared to $59.1 \%$ among hemophiliacs in Denmark, where commercial clotting factor concentrate from the United States is used. Among European hemophiliacs who used both local and commercial factor VIII concentrate, the prevalence of HTLV-III antibodies was unrelated to the dose of local concentrate but was significantly related to the dose of commercial concentrate ranging from $10 \%$ seropositive among the lightest users to $80 \%$ seropositive among the heaviest users of commerical factor VIII concentrate (19). Heat treatment of factor VIII concentrate may be effective in neutralizing the virus and reducing or eliminating the risk of transmission (20).

Serial samples stored at hemophilia centers in the United States and Europe have been retrospectively tested for HTLV-III antibodies. Virtually every center utilizing commercial factor VIII concentrate from the United States shows that HTLV-III antibodies first appeared in hemophiliacs in 1979 and that seroconversion among the hemophilia population occurred rapidly during 1981 and $1982(21,22)$. The interval between the appearance of HTLV-III antibodies (1979) and the appearance of AIDS (1981-'82) among hemophiliacs fits well with the typical incubation period of 2 or more years that has been noted in cases of transfusion-associated AIDS (23). Recently, it has been noted that hemophiliacs who have been HTLV-III seropositive for 3 or mone years may all have developed lymphadenopathy, a low helper T-cell count $(<400$ cells) $\mathrm{mm}^{3}$ ), or both (22). In contrast, hemophiliacs who have been HTLV-III seropositive for less than 3 years have significantly lower rates of lymphadenopathy and intermediate or normal helper T-cell counts. These findings confirm the long incubation period which may have no clinical manifestations and also suggests that the vast majority of HTLV-III infected persons may develop lymphadenopathy, a low helper T-cell count, or both $(22)$.

\section{HTLV-III and AIDS in Other Groups}

In addition to homosexual men and patients with hemophilia, increased rates of AIDS have been noted among parenteral drug users, transfusion recipients, heterosexual contacts and in fants of persons at high risk of AIDS, and persons of Haitian or central African origin (1). As was found in homosexual men and hemophiliacs, prevalence rates of AIDS and HTLV-III seropositivity are concordant in parenteral drug abusers, with high rates in the New York -metropolitan area $(1,24)$. Analytic epidemiological studies of HTLV-III and AIDS among parenteral drug abu- sers have not yet been reported. Likewise, the prevalence of HTLV-III antibodies among heterosexual contacts of some persons with AIDS may be high (25), and female prostitutes may be a major reservoir of HTLV-III that could be spread to the heterosexual population. These potential AIDS-risk groups have not been studied in detail. There also appears to be a high risk of maternal-fetal transmission of HTLV-III in the younger siblings of a child born with AIDS $(26,27)$, and the possibility of postnatal transmission via close maternal-infant contact such as breast feeding has been suggested (28). As for transfusion recipients, HTLV-III and its antibodies have been found in most transfusion-associated AIDS patients and in their blood donors (29).

Among persons with no apparent risk for AIDS, the rate of HTLV-III seropositivity appears to be relatively high (approximately 12\%) among persons in some areas of central Africa and low (0-5\%) among Haitians in the United States or Haiti (30-32). Preliminary indications suggest that having numerous heterosexual partners may be a risk factor in these areas, but other possibilities (e. g., other retroviruses which crossreact in the HTLV-III antibody assay) have not been thoroughly investigated.

\section{HTLV-III and the Risk of AIDS}

Among members of high-risk groups in the United States, the cumulative incidence of AIDS 32 months following the detection of HTLV-III antibodies has ranged from 4-20\% (33). Homosexual men in New York City had a significantly higher rate of AIDS (20\%) than did persons in other cities or other risk groups. This difference could be accounted for by 5 cases of Kaposi's sarcoma which occurred only among the homosexual men in New York and which may have additional cofactors (e. g., nitrite inhalant use). Alternatively, because homosexual men in New York have been at the AIDS epicenter, it is possible that cofactors are irrelevant and that they have simply had a longer time at risk following seroconversion. Additional follow-up will be required, particularly given the incubation period which may extend beyond five years (23). However, in either case, it is already clear from the HTLV-III seroepidemiological evidence that HTLV-III is the primary etiologic agent of AIDS, that secondary factors may or may not contribute to the subsequent risk of AIDS, and that a long incubation period, frequently exceeding 2 years, may elapse between initial HTLV-III infection and the appearance of a life-threatening opportunistic infection or malignancy. It is also very clear from the epidemiological evidence that HTLVIII is readily transmitted by intimate sexual con- 
tact and by parenteral injection of contaminated blood. In contrast, neither AIDS nor HTLV-III seropositivity has been associated with non-sexual contact with AIDS patients or persons at high risk of AIDS (1).

These observations call for widespread public health education programs to limit homosexual and heterosexual transmission, to reduce the use and sharing of contaminated needles by parenteral drug users, to encourage contraception by women at high risk of HTLV-III infection, and to minimize transfusion-associated AIDS by the voluntary exclusion from blood donor pools of persons at high risk of AIDS and their heterosexual partners and by the widespread screening of all blood and plasma donors for HTLV-III antibodies (34). Using these measures, it should be possible to limit the AIDS epidemic. With the long incubation period, however, such success may not be evident for several years.

\section{Note added in proof:}

The appearance of HTLV-III antibodies in homosexual men in San Francisco in approximately 1978, the rapid increase in seroprevalence during the subsequent 6 years, and the 2-3 year latency period between seroprevalence and the AIDS epidemic have been reported recently (35).

\section{REFERENCES}

1. Goedert J.J., Blattner W.A. (1985): The epidemiology of AIDS and related conditions. In AIDS: etiology diagnosis, treatment and prevention V.T. De Vita Jr., S. Hellman, S.A. Rosenberg, (editors), J.B. Lippincott Co, Philadelphia, pp. 1-30.

2. Fahey J.L., Prince H., Weaver $M$. et al. (1984): Quantitative changes in $\mathrm{T}$ helper or $\mathrm{T}$ suppressor/ cytotoxic lymphocyte subsets that distinguish acquired immune deficiency syndrome from other immune subset disorders. - Am. J. Med., 75: $95-100$.

3. Popovic M., Sarngadharan M.G., Read E., Gallo R.C. (1984): Detection, isolation, and continous production of cytopathic retroviruses (HTLV III) from patients with AIDS and pre-AIDS. - Science, 224: $497-500$.

4. Gallo R.C., Salahuddin S.Z., Popovic M. et al. (1984): Frequent detection and isolation of cytopathic retroviruses (HTLV III) from patients with AIDS and at risk for AIDS. - Science, 224: 500-503.

5. Barre-Sinoussi F., Chermann J.C., Rety F. et al. (1983): Isolation of a T-lymphotropic retrovirus from a patient at risk for acquired immune deficiency syndrome (AIDS). - Science, 220: 868-870.
6. Levy J.A., Hoffman A.D., Kramer S.M. et al (1984): Isolation of lymphocytopathic retroviruses from San Francisco patients with AIDS. - Science, 225: $840-842$.

7. Groopman J.E., Salahuddin S.Z., Sarngadharan M.G. et al. (1984): HTLV-III in saliva of people with AIDS-related complex and healthy homosexual men at risk for AIDS. - Science, 226: 447-449.

8. Zagury D., Bernard J., Liebowitch J. et al. (1984): HTLV-III in cells cultured from semen of two patients with AIDS. - Science, 226: 449-451.

9. Ho D.D., Schooley R.T., Rota T.R. et al. (1984): HTLV-III in the semen and blood of a healthy homosexual man. - Science 226: 451-453.

10. Salahuddin S.Z., Markham P.D., Popovic M. et al. ( ): Isolation of infectious HTLV-III from AIDS and ARC patients and from healthy carriers: a study of risk groups and tissue sources. Proc. Natl. Acad. Sci. (in press).

11. Broder S., Gallo R.C. (1984): A pathogenic retrovirus (HTLV-III) linked to AIDS. - N. Engl. J. Med. 311: 1292-1297.

12. Gallo R.C., Shaw G.M., Marhan P.D. (1985): The etiology of AIDS. In: AIDS: etiology, diagnosis, treatment and prevention (V.T. De Vita Jr., S. Hellman, S.A. Rosenberg, editors), J.B. Lippincott Co, Philadelphia, pp. 31-54.

13. Gallo R.C., Sarngadharan M.G., Popovic M. et al. ( ): HTLV-III and the etiology of AIDS. - In: Progress in Allergy, Vol. 137 (E. Klein, editor), Karger, Sweden (in press).

14. Weiss S.H., Goedert J.J., Sarngadharan M.G. et al. (1985): Screening test for HTLV III (AIDS agent) antibodies: Specificity, sensitivity and applications. - JAMA 253: 221-225.

15. Goedert J.J., Sarngadharan M.G., Biggar R.J. et al. (1984): Determinants of retrovirus (HTLV III) antibody and immunodeficiency conditions in homosexual men. - Lancet, ii: 711-716.

16. Melbye M., Biggar R.J., Ebbsen P. et al. (1984): Seroepidemiology of HTLV III antibody in Danish homosexual men: Prevalence, transmission and disease outcome. - Br. Med. J., 289: 573-575.

17. Hardy A.M., Allen J.R., Morgan W.M. et al. (1985): Incidence of AIDS in selected population groups. JAMA, 253: 215-220.

18. Goedert J.J., Sarngadharan M.G., Eyster M.E. et al. (1985): Antibodies reactive with human T-cell leukemia viruses (HTLV-III) in the sera of hemophiliacs receiving factor VIII concentrate. Blood, 65: 492-495.

19. Melbye M., Froebel K.S., Madhok R. et al. (1984): HTLV-III seropositivity in European hemophiliacs exposed to factor VIII concentrate imported from the USA. - Lancet, ii: 1444-1446. 
20. Rouzioux C., Charmaret S., Montagnier L., Carnelli V., Rolland G., Mannucci P.M. (1985): Absence of antibodies to AIDS virus in hemophiliacs treated with heat-treated factor VIII concentrate. - Lancet, i: $271-272$.

21. Gurtler L.G., Wernicke D., Eberle J., Zoulet G., Deinhardt F., Schramm W. (1984): Increase in prevalence of anti-HTLV-III in hemophiliacs. . Lancet, ii: 1275-1276.

22. Eyster M.E., Goedert J.J., Sarngadharan M.G, Weiss S.H., Gallo R.C., Blattner W.A. (1985): Development and early natural history of HTLV-III antibodies in persons with hemophilia. - JAMA, 253: $2219-2223$.

23. Curran J.W., Lawrence D.N., Jaffe H.J. et al. (1984): Acquired immunodeficiency syndrome (AIDS) associated with transfusions. - N. Engl. J. Med., 310: 69-75.

24. Spira T.I., Des Jarlais D.C., Marmor M. et al. (1984): Prevalence of antibody to lymphadenopathy-associated virus among drug-detoxification patients in New York. - N. Eng1. J. Med., 311: 467-468.

25. Redfield R.R., Markham P.D., Salahuddin S.Z. et al. (1985): Frequent transmission of HTLV-III spouses of patients with AIDS-related complex and AIDS. - JAMA, 253: 1571-1573.

26. Scott G.B., Fischl M.A., Klimas N. et al. (1985): Mothers of infants with acquired immunodeficiency syndrome: evidence for both symptomatic and asymptomatic carriers. - JAMA, 253: 363-366.

27. Scott G.B., Fischl M.A., Klimas N., Fletcher M., Dickinson G., Parks W. (1985): Mothers of infants with the acquired immunodeficiency syndrome (AIDS): Outcome of subsequent pregnancies. Proceedings of the International Conference on Acqui- red Immunodeficiency Syndrome (AIDS). - U.S. Public Health Service, Atlanta.

28. Ziegler J.B., Cooper D.A., Johnson R.O., Gold J., Sydney AIDS Study Group (1985): Postnatal transmission of AIDS-associated retrovirus from mother to infant. - Lancet, i: 896-898.

29. Feorino P.M., Jaffe H.W., Palmer E. et al. (1985): Transfusion-associated acquired immunodeficiency syndrome: evidence for persistent infection in blood donors. - N. Engl. J. Med., 312: 1293-1296.

30. Biggar R.J., Melbye M., Kestens et al. (1985): Seroepidemiology of HTLV-III antibodies in a remote population of eastern Zaire. - Brit. Med. J., 290: $808-810$.

31. Vande Perre P., Munyambuga D., Zissis G., Butlzer J.P., Nzaramba D., Clumeck N. (1985): Antibody to HTLV-III in blood donors in central Africa. - Lancet, i: 336-337.

32. Frank E., Weiss S.H., Compas J.F., et al. ( ): AIDS in Haitian-Americans, a reassessment. - Cancer Res. (in press).

33. Goedert J.J., Weiss S.H., Biggar R.I. et al. (1985): Natural history of HTLV-III seropositive persons from AIDS risk groups. Proceedings of the International Conference on Acquired Immunodeficiency Syndrome (AIDS). - U.S. Public Health Service, Atlanta.

34. Goedert J.J. (1985): Blood donation by persons at high risk of AIDS. - N. Engl. J. Med., 312: 1190.

35. Jaffe H.W., Darrow W.W. Echenberg D.F. et al. (1985) The acquired immunodeficiency syndrome in a cohort of homosexual men: A six-year followup study. - Ann. Intern. Med,, 103: 210-214. 